\title{
Märkidega kivid ja peidetud varandused
}

\author{
Mare Kalda
}

\section{Loodusobjektist kultuuriruumi märgiks}

Loodusobjekt (puu, kivi, küngas, veekogu, metsasalk) on vaadeldav märgina maastikus. Kui ühte või teist sellist esitatakse muistendi tegevuskohana, saab temast ühtaegu ka kultuuriruumi märk, temast tehakse suhtluses juttu. Mall Hiiemäe on sellest aspektist analüüsinud puude teemat meie traditsioonis (teesidena Hiiemäe 2000a, tervikkäsitlus ilmumas IX soome-ugri kongressi ettekannete kogumikus). Tema seisukohad jäävad kehtima, kui võrrelda pärimust puudest pärimusega kividest. Näiteks kirjutab M. Hiiemäe: Põlispuu omandab nii maastikus kui konversatsioonis topograafilise leppemärgi, orientiiri staatuse. Nime kaudu identifitseerituna on niisugune leppemärk igapäevaolmes vajalik. Ja veidi edasi: Maastikus pilku püüdva puuga kujuneb inimestel assotsiatiivne suhe, mis väärtustab nende jaoks seda puud (Hiiemäe 2000b: 1).

Samamoodi võivad märgiliseks saada kivid, millel on omakorda märgid. Ka muistendisüžeed on traditsioonis olnud sarnased (kuigi leidub ka spetsiifilisi): ohvripuu või kivi, puu kahjustaja või kivi koha muutja saab karistada, puu või kivi rändab, pulmalised muunduvad puudeks või kivideks, puu või kivi lähedusse on peidetud varandus, Karl XII on puu istutanud või selle juures viibinud või kivil lõunatanud, puu või kivi tähistab tapmis- või matusekohta, puu või kivi läheduses eksitakse ja seal kummitab (Hiiemäe 2000a: 27 ja Hiiemäe 2000). Kui näiteks puu - Mall Hiiemäe mõttekäiku järgides - saab kultuuriruumi märgiks, siis eeldab see kas vastava kinnitava narratiivi loomist ja/või vastavalt tegutsemist (toimingud püha puu juures, kahjustamise vältimine). Seevastu kivi sõna otseses mõttes tehakse märgiliseks, kui sinna raiutakse sümboleid. Narratiivne ja tegevuslik aspekt muidugi ei puudu. Osa sümboleist "raiutakse" siiski üksnes jutus, kuivõrd otsitakse seletusi märke meenutavatele looduslikele kujunditele-süvenditele kivil. On olemas veel võimalus, mis toimib eelkõige piirikivide tähistamisel. Sel juhul tarve jutu loomiseks puudub, märgi ja tähistatava vahel on üksühene suhe. Interpretatsioonid algavad, kui algne ja/või õige tähendus ununeb ka sotsiaalsest mälust. 
Kui muistendites varjul olev mõttemaailm ja mõttemallid pole marginaalne teema, siis praegu vaatluseks valitud alateema kindlasti on. Kivide hulk Eestis on suur, rahvajuttudega seotud kivide hulk mõnevõrra väiksem. Kummagi hulga alahulgad on vastavalt märkidega kivid ja aardemuistendid, mis sellistega seoses. Paralleelselt rahaaugu juttudele pööran mõnevõrra tähelepanu ka muule pärimusele kividest. Sest märke ühel ja samal kivil võidi juttudes tõlgendada erinevalt ning ühe ja sama märkidega kivi kohta võis käibida temaatiliselt erisugust pärimust. Samal põhjusel osutan muistenditele, milles varanduse peidukoht on hoopis mäel või kus märkidest kivil ei teatata. Kivi on muistendeis varandusekoha orientiir üsna sageli ja seda pole raske mõista. Kivi näib piisavalt püsiv ja vajadusel taasleitav. Et sellisel orientiiril leidub veel lisasümboleid, on haruldasem olukord. Selliste kivide traditsiooniga tutvujal tekivad mõningad tähelepanekud ja küsimused, mis ehk väärivad esile toomist.

Enn Ernits küsib kaljujoonistest kirjutades, kas Eestist võiks petroglüüfe leida, ja viitab Jaan Jungi tähelepanekutele, et neid tuleks veel otsida (Ernits 1997: 26 ja käesolev kogumik). Meie kivijooniste hulgast (niivõrd, kuivõrd neid on) puuduvad kõikvõimalikud lindude, loomade, inimeste, taevakehade, liiklusvahendite kuju-

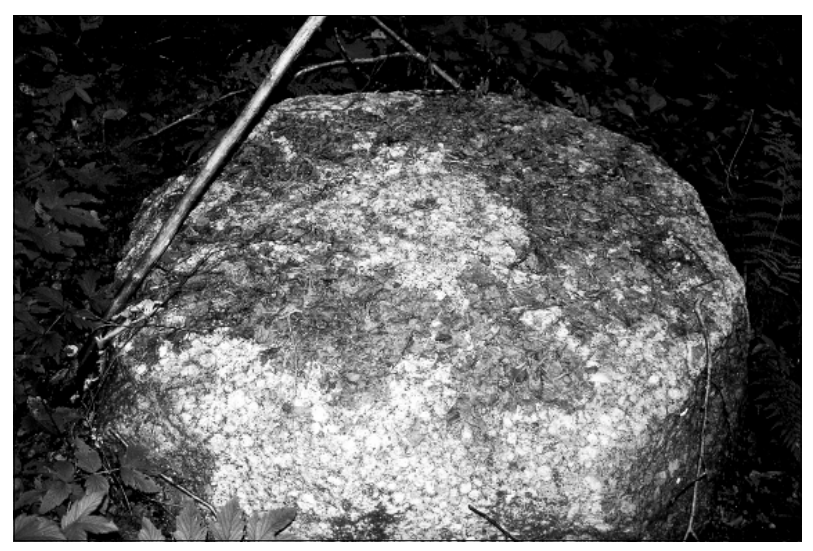

Joonis 1. Punktiga ring kivil Virunuka tarandkalmete läheduses Rõuge kihelkonnas. Kohalik rahvas peab piirikiviks. Alkeemias tähistab selline sümbol kulda. Miks sellel kivil leidub niisugune sümbol, ei tea. Foto: M.-A. Remmel (ERA fotokogu $\mathrm{nr} 2109$ ). 
tised, millele Ernits ja kõik kaljujooniste iseloomustajad osutavad (Tenjes 1986: 85-88; ka Poikalainen http://www.suri.ee/esy/leht/ 99poi.html ja Jõekalda http://www.obs.ee/ emts/ajakiri/ kes_raius_pildid_kaljupinda.html). Muistendiüleskirjutustes kirjeldatakse märkidena riste, auke ja lohke, lamamisjälgi, loomade või inimeste jäetud jala- või käejälgedena tõlgendatavaid märke, leidub terariista kujutisi, harva punktiga ringi (kas piirimärk?), tähti ja numbreid ning nende kombinatsioone.

Rahvapärimuse järgi on ristimärgid kividele tehtud sageli matuse- või hukkumiskoha tähistuseks. Sellega seoses on niisuguste kivide otstarbele tähelepanu pööranud arheoloogid. Näiteks Heiki Valk on analüüsinud teemat Lõuna-Eesti külakalmistute uurimise kontekstis. Ta järeldab, et kalmet tähistab kivirist või ristimärgiga kivi siiski harva, vaid 9,7\%-l kõigist teadaolevaist kalmetest on niisugune seos täheldatav (tõsi - me ei tea täpselt, kui palju oli või on ristimärkidega kive ja kiviriste üldse). Ning nendelgi juhtudel on ülekaalus kiviristid (96 kiviristi 20 ristimärgiga kivi vastu Lõuna-Eestis, Valk 1999: 25 joonis 12). Kiviristide paigutamine erilise sündmuse toimumise kohta oli keskaegse Euroopa traditsioon, mis arvatavasti Eestiski kuigivõrd kajastus (Valk 1999: 24-25). Seda kõike teades ei tundu mälestuskivi asetamine liiklusõnnetuse paika tänapäeval ka selles mõttes hilise ega kontekstivälise nähtusena.

H. Valk toob esile ka tõsiasja, et paljud niisugused mälestusmärgid kadusid - kas võeti maha, lõhuti või kasutati mujal - juba 17. sajandil.

Andres Tvauri on uurinud põhjalikult väikeselohuliste kultuskivide tähendust ning ohvrikivide traditsiooni, seda arheoloogia ning folkloristika tähelepanelikus sümbioosis (Tvauri 1997: 11-53 ning http://haldjas.folklore.ee/folklore/vol11/stones.htm ja 1999: 3457 ning http://haldjas.folklore.ee/tagused/nr11/kivi.htm).

Mitmed vaatlused kividest meie rahvapärimuses on keskendatud erinevatele üksikküsimustele. Vastavat pärimust sisaldab Jaan Jungi mitmeköiteline teos, mis kannab pealkirja Muinasaja teadus Eestlaste maalt, määratles käsitluse žanri tabavalt ning see oligi mõeldud muististe registrina.

Traditsiooni vahendava väärtusega on Ali Kikkase kirjutis Võrumaa märkidega kividest Kaika suveülikooli kogumikus (Kikkas 1997). Ta loetleb 12 juhtumit, kus märkidega kivi on lõhutud või selle asukohta on muudetud ehituste või maaparandustööde tõttu. 
Tegelikult ei peaks üle tähtsustama arvamust, nagu oleks märkidega kivi kasutamine mujal tingimata taunitav. Motiivid sanktsioonidest kivi nihutamise tagajärjel on kindlad juhtumid, mis on ühenduses kindlate kohtadega (siin kividega).

Reet Hiiemäe annab ülevaate eelkõige Käsmu ümbruse tuntud kividest, sest omapärase ürituse - Käsmu kivipäeva - korraldajad Eesti Maaparandajate Selts ja Käsmu Meremuuseum olid huvitatud kivide folkloristlikust tutvustusest. R. Hiiemäe esitab muu hulgas üldisi tähelepanekuid kividest traditsioonis, täpsemalt usundis ja muistendeis. Esimese grupi kivid aitavad kindlustada nii loomade kui ka inimeste head käekäiku ja edenemist (õnnekivid, kaarnakivi, ohvrikivid). Teised kivid seonduvad käitumisreegleid selgitavate rahvajuttudega (kiviks muudetud inimesed). Järgmise rühma kividest kui pilkupüüdvatest märkidest maastikul käibis mõjult neutraalsemaid, kirjeldavat laadi tekste (põllekivid, istekivid, näljakivid jts; Hiiemäe 2000: 66). Nn mõrsjakivide tähendust looduses ja (koha)muistendis analüüsib Mari-Ann Remmel (käsitlus ilmumisel, $e$-teesid http://www.zbi.ee/ uexkull/estonian/jyripaev.htm\# Remmel). Mõistagi on kive kui jutuobjekte pärimuses vaadelnud teisedki folkloristid, eriti kohamuistendite piirkondlikes ülevaadetes.

Tegelikult on kivi vastavateemalises pärimuses peidetud varanduse orientiiriks sageli. Enamasti jääb selline kivi jutust saadava mulje varju, jutusüžee mõjub nii intensiivselt. Kui kivi olemasolust on teatatud, seos maastikul leiduva tegeliku märgiga igakordsel jutukstulekul uuesti sõnastatud, keskendub vestlejate tähelepanu ja muistendi retseptsioon süžeele: mis selle kivi juures siis on, mis seal juhtus või võiks juhtuda. Aardemuistendites ei juhatata varandusi otsima tingimata tohutu suure, silmapaistva kivimüraka alt. Varandusekivi võib olla isegi suvaline märkamatu või vähe silmatorkav kivikülg heinamaa servas või õue all. Kivil võib leiduda sümboleid, sel juhul on kivi märk, millele on raiutud lisamärgid.

Siinses vaatluses selgub, kuidas varanduse orientiiriks olemine pigem ei mõjuta kivile erilise nime andmist, spetsiifilise mikrotoponüümika loomist (tunti rahakivi, mitte Rahakivi). Vastupidised juhtumid on tõenäoliselt ühekordsed ega vahenda traditsiooni.

Sissejuhatavalt peaks esile tooma asjaolu, et lisaks teadmisele märkidega kivist kui varanduse peidukoha tähistajast on samast kivist paralleelselt jutustatud teistsuguseid muistendeid. Paljudel juhtudel tulekski viimati toodud lause osad vahetada: samast kivist 
on jutustatud mitmesuguseid muistendeid ning neile paralleelselt teatakse sama märkidega kivi kui peidetud varanduse orientiiri. Erinevad süžeed võisid olla tuttavad samale informandile ning rahvaluulekoguja küsimise peale need ka esitati. Sõltuvalt pärimuse levikust ruumis ja ajas ei ole niisuguseid erinevaid jutuarendusi sama loodusobjekti, siin siis märkidega kivi kohta lõputult palju. Sellega seoses ilmnevad teatud suundumused omapärasele spetsialiseerumisele, hiidude viske- ja kandmiskivid on eraldi varanduse märgukividest või kui ikkagi mõlemad süžeed sama kivi kohta käibivad, on neid üles märgitud silmatorkavalt lahus hoituna. Ka ohvri- ja nn arstikivid osutavad suhteliselt harva peidetud varandusele. Muistsed (või hilisemad) kalmed on pärimuses eelduslikud varanduste peidukohad, kuid neil juhtudel on mingile ühele kivile osutatud harva.

\section{Suur ja väike. Märgatav - vähemärgatav}

Peidukohta tähistav kivi pidi olema leitav, kuid mitte väljakutsuv, liigset tähelepanu tekitav. Seda nii tegelikult kui ka loodud, s.t jutureaalsuses. Nõnda võidakse küll ka rahajutus öelda, et aare peitub suure kivi all, kuid see kivi on suur vaid suhteliselt. Maastikumärkide muistendiks jutustamisel toimub omapärane spetsialiseerumine. Ikka tõepoolest suured kivid viidi enamasti seosesse hiidude või vanapagana tegevusega, näiteks suured kivid Pärispea poolsaarel: Painuva kivi, Odakivi, Tiirukivi, Sorrukivi, Mustkivi. Inimesesuurused ja -kujulised kivid võisid olla mingisuguse keelu eiramise tõttu kiviks muudetud normirikkujad või nende valel ajal tehtud töö saadused (näiteks töötasid pühal ajal). Rahaaugujutud samast kandist - need, kus raha olevat kivi all - osutavad pigem väliselt tähtsusetule nimetule kivile (näiteks kedagi Viinistu inimest juhatati unenäos Heigijaani õue viltuse kännu ja kivi juurde; ERA II 222, 122/3 (27) < Kuusalu, Viinistu - U. Heinakroon Viinistu algkoolist < tundmatu informant (1939)). Tiirukivi mainitakse küll ühes varandusejutus, kuid leiu seisukohalt juhatab see sündmuspaigale ainult natuke lähemale. Selles muistendis kündis talumees arvatava varanduse juhuslikult välja, ader takerdus katla taha, hobused jäid seisma ning mees läks vajalikku tööriista otsima. Tagasi tulles leidis ta palja katlasanga (ERAII 222, 233/4 (6) < Kuusalu, Viinistu - L. Kempman Viinistu algkoolist < August Randma, 
41 a (1939), soome tüpoloogias tüüp P 531). Niisuguses jutuarenduses - arvatav varandus ilmub juhuslikult mingi töö tegemise käigus - osutatakse peidukohakivile harva. Iseasi, et polnud välistatud juhtumid, kus adra peatas algul väljapaistmatu kivi vao sees. Aardemuistend mängib tema jutustajate-kuulajate erilistel lootustel. Korraga vajatakse nii kinnitusi, et varandusi on võimalik leida, kui ka põhjendusi, miks sellest ilma jäädakse. Kui peidukoht asuks tohutu kivimüraka vahetus läheduses, muutuks hilisem ülesleidmine küsitavaks. Kivi (suhteline) suurus võidakse esitada argumendina, miks varandust kätte ei saada. Näiteks oli leidmata rootslaste oletatav vara ühe kivi alt muistenditundja naabertalu maal Säre külas, sest keegi ei suutnud kivi liigutada (ERA II 243, 395 (3) < Urvaste, Vana-Antsla v, Säre k - H. Kirschenberg Antsla algkoolist < Arnold Kirschenberg, üleskirjutaja isa, 47 a (1939)).

Kui varandus ei pidanudki otseselt kivi all peituma, siis ka otsimine paraja suure rändrahnu ümbrusest oleks hea tükk tööd.

Niisiis ei ole tõeliselt suured kivid tingimusteta soosikud aarde peidukohta tähistama. Pole kohanud rahvapärast üldistust, et suuremate kivide juurde (alla) olevat ikka varandusi peidetud. Küll aga leidub selline tõdemus märkidega kivide kohta: Varandused olevat peidetud sinna, kus on niisugune kivi, kuhu on pääle kirjutatud või midagi märki tehtud (ERA II 241, 445/6 (10) < Kambja, Kodijärve v < Kambja v - A. Kukk Luke algkoolist < sõtse Heleene Jakobson, 41 a (1939)). Seda ei tule muidugi võtta absoluutsena.

Et hiljem oleks võimalik suhteliselt väheatraktiivset märgukivi ära tunda, võidi sinna raiuda sümboleid, ning teisipidi - märgid kivil võisid anda tuge aardejutu edasikestmiseks. Arvatavasti on märke, jooni ja kujundeid kividel varanduse asupaiga kaardistuseks peetud sagedamini, kui selleks tegelikult põhjust oli.

\section{Jäljed kividel}

Selles kontekstis on harilikud muistendid, milles seletati mitmesuguste jälgede tekkimist ja saamist kivile. Üpris järjekindlalt tõlgendati pärimuses mitmesugusteks jälgedeks kultuskivide lohukesed, kuid küllap ka looduslikud süvendid. Lohukive leidub rohkesti just Põhja-Eestis (A. Tvauri http://haldjas.folklore.ee/folklore/ vol11/pics/tv2.htm). Samasisulisi jälje seletusmuistendeid on üles märgitud ka Lõuna-Eestist, kus lohukive vähe leida. Näiteks Vana- 
pagana käpajäljega viskekivi on Uhtjärve ääres (ERA II 243, 309 (11) < Urvaste Vastse-Antsla v - E. Narits, Kuldre algkoolist < Juuli Kangro, 67 a, üleskirjutaja vanaema (1939)) ja vanapagana astutud palja jala jäljega kivi on olnud Vaabina vallas Liiva talu heinamaal (ERA II 243, 393 (2) < Urvaste, Vana-Antsla v, Säre k - H. Kirschenberg, Antsla linna algkoolist < Arnold Kirschenberg, 47 a, üleskirjutaja isa (1939)).

Varieeruvad seletused sellest, kuidas jäljed tekkisid. Need tegi kord Kalevipoeg (või tema hobune), kord Vanapagan (või tema hobune), kord pole kumbagi nimeliselt esile toodud. Näiteks hobuse jälg on kivil Kõnnu Vanaküla Pohla talu maal (ERA II 222, 397 (18) < Kuusalu, Kõnnu v, Kalme k - Ilse Lehesalu, Kõnnu täienduskool < Maali Pärn, 69 a (1939)). Hästi tunti üleni jälgi täis kive Jahukaril, need pidid olema inimkäe ja -jalajäljed ning loomasõrgade jäljed, lisaks veel lapse magamisaseme jälg sellest ajast, kui kivid olnud veel pehmed (ERA II 222, 677/8 (1) < Jõelähtme, Prangli v-A. Hein, Prangli algkool < Anna Lusman, 70 a (1939)).

Kui sellisesse muistendisse lisandus varanduseteade, siis igal juhul puudub süžeeline seos jälgede tekitamise, s.t märkide saamise ja varanduseteema vahel. Jäljega kivi on neil juhtudel aardejutu kohakirjelduse tavaelement. Selle poolest erinevad jälgedega kivide varanduseteated nendest, kus ka märgi tegemisest on jutustatud seoses varanduse peitmisega.

Varanduse märgukiviks on just hiiu jälgede seletusjutu kaudu tuntud kivi väga harva. Näiteks Kalevipoja muistendite hulgas on vähemalt 90 jutuvarianti sümbolitega kividest (hiiu sõrmejälgedega viskekivid ja astumise jäljed). Nendest ainult kolmes leidub ühes ja samas tekstis ka paralleelne aardesüžee (muistendid nr 45B, 101 ja 381, Laugaste \& Normann 1959: 175, 197, 433). Samas on märgatud teatud traditsioonisisest eristumist, kuivõrd jälgedega kivideks on märgitud suuremaid või muidu silmapaistvaid kive, mis soosis hiiumuistendi tähendusi. Teine oluline tähelepanek on selliste kivide ja lugude rohkus Läänemaal, kus tegelasteks ühevõrra nii Kalevipoeg kui vanapagan (Laugaste \& Normann 1959: 526).

Hiiu tegevuse seletus ja varandusjutt püsivad enamasti lahus (erinevad jutud sama kivi kohta) ning igasuguste kujutiste seletustes oleks justkui eelistatud hiiu versiooni. Näiteks Kullamäe talu maal olnud sümbolitega kivist on teada variant Kalevipoja-seletu- 
sega (E 48183/4 < Võnnu), kuid on kogutud ka eri tüüpidesse kuuluvaid aardemuistendi teisendeid (näiteks kogus RKM I 5). Kas peaks arvama, et peidetud varanduse muistendid pigem ei kontamineeru näiteks muistenditega hiidudest ning muistenditega vanapaganast kontamineeruvad pigem (või ainult) kindlate jututüüpide kaudu ja siis on tegu juba kuradi, mitte niivõrd vanapagana kui loodushiiuga?

Küll aga on märkidega kivi kui varanduse tähistaja tavalisem sellistes mitmesuguste jälgede seletamise muistendeis, kus hiidu ei mainita, ja selliste loodusobjektide puhul, mille kohta pole teada, et sellest oleks üldse olnudki hiiumuistendit.

Näiteks suure kivi külg Viruvere Jaagu väljal meenutas trepiastmeid, kivil olid jalajäljed ja läheduses varandus peidus (ERA II 221, 41/2 (1) < Peetri, Koigi v, Keri k < Viruvere k - H. Renter, Kareda algkool < Marie Neipauer, 67 a, üleskirjutaja vanaema (1939));

Iisaku Metskülas oli Pasti mägi, millel kivis inimese ja kitse jälg ning läheduses pidi peituma õlleankrutäis kulda (ERA II 215, 411 (1) < Iisaku - E. Parve, Iisaku algkool < Ann Peedu, üleskirjutaja vanaema (1939)).

Ka Helme orjakivist on teada varandusejutu variant. Siin saab karjane küll kulla kätte, kuid see muutub haavalehtedeks, kui leidja vahepeal loomi vaatamas käib (ERA II 236, 619/20 (10) < Helme, Koorküla v - S. Jõemets < Asta Jõemets, s 1927 (1939)).

Varandus olevat peidetud jälgedega kivi lähedusse Vastseliina vallas Remeski metsas:

Remmeski kivi asub Vastseliina vallas Remeski metsas. Remmeski kivi on saanud kuulsaks oma saladuste poolest. Sellel kivil olevat peal inimese jala jäljed ja hobuse raua jälg. Selle kivi ümbruses olevat peidus varandusi. Kogu poolest olevat see kivi väga suur. Sinna olevat käinud mitmed inimesed varandusi otsimas. Kivi ümbrus olevat ringi kõik auke täis kaevatud. Sealt olevat keegi mees raha ka juba leidnud, aga seda ei teata, kas see jutt vastab tõele. Kord olevat käinud kaks meest seal kaevamas, nendel olid olnud kõik kaevamisabinõud kaasas. Kaevamisega olid saanud vaevalt alata, kui tulnud kaks suurt valget hagijat, mehed olid hakanud kartma ja jooksnud minema. (ERA II 243, 143/5 (5) < Kanepi, Erastvere v, Seegemi k - J. Tsekker, Erastvere Suureküla Algkool < Pavel Tsekker, 47 a, üleskirjutaja isa (1939).) 
Kui märkideks kividel on jäljed või õigemini jälgedeks seletatud lohud, ei ole märk tehtud varandusekoha tähistuseks. Taasleidmise orientiiriks on võetud sel juhul juba märgistatud kivi.

\section{Tähed, kirjad, numbrid}

Nagu ristimärke, peeti ka kirjatähti ja jooniseid kivil kellegi hauavõi hukkumiskoha tähistuseks (kui just ei olnud tegu teadaoleva piirimärgiga).

Tähed A, M ja K suurel kivil Laimjala vallas Kälta külas Tooma talu karjamaal näiteks pidid tähendama kivi alla maetud kolme ohvitseri nimetähti (ERA II 221, 425 (41) < Türi, Alliku v, Mäeküla < Pöide, Laimjala v, Kälta k - V. Tõnissoo, Türi Progümnaasium < Melaani Pihelgas, 47 a, üleskirjutaja tuttav (1939)).

Mooste metsas Kadaja külas Aarniku vahtkonnas oli aga saksakeelsete kirjade ja aastaarvuga kivi. Selle juurde juhatati kedagi unenäos varandust otsima, kuid nägija ei söandanud uurima minna (ERA II 241, 52 (12) < Võnnu, Ahja v, Valgesoo < Põlva, Mooste v K. Lodjak, Ahja algkool < Miili Lodjak, 62 a, üleskirjutaja vanaema (1939)). Kui teada, et vanaaegsed kalmed liidavad rahvajutte peidetud varandustest kergesti, siis võib ka siin niisugune seos toimida. Samas metsas asubki vanaaegne matusekoht.

Ühes üleskirjutuses nimetatakse risti, mõõka, võtit ja kirvest kivil kunagise Sangaste metskonna ja Kassi vahtkonna piiril (ERA II 243, 269 (27) < Urvaste, Vastse-Antsla v - L. Kallion, Kuldre Algkool < Matli Pihl, 77 a (1939)). Kivi olevat osalt maa sees, osalt väljas ning selle alla olevat maetud 28 1905. aasta sündmustes langenut (sümboleid nimetas informant Musta sõja mälestuseks). Selles ajaloolises pärimuses ei mainita peidetud varandusi. Kas sama kivi on jutuks M. J. Eiseni järgmises teates?

Uue-Antsla Kõrtsimäest kõneldakse, sellesse matnud rootslased sõja ajal kaks tündrit või pütti kulda. Märgiks, kuhu vara maetud, pannud rootslased mäele kivi, millele nad risti, võtme ja ankru peale raiunud. 15 sülda kivist eemal - ometi teadmata, missuguses sihis - peitub rootslaste kuld. Kulda on sealt mitmel puhul otsitud, aga et õige siht tundmata, ei ole midagi leitud (E $57340<$ Tartu linn M. J. Eisen < Krüner ja Eisen 1928: 218).

Mingisugused märgid on olnud Sänna mõisa pargis oleval kivil: 


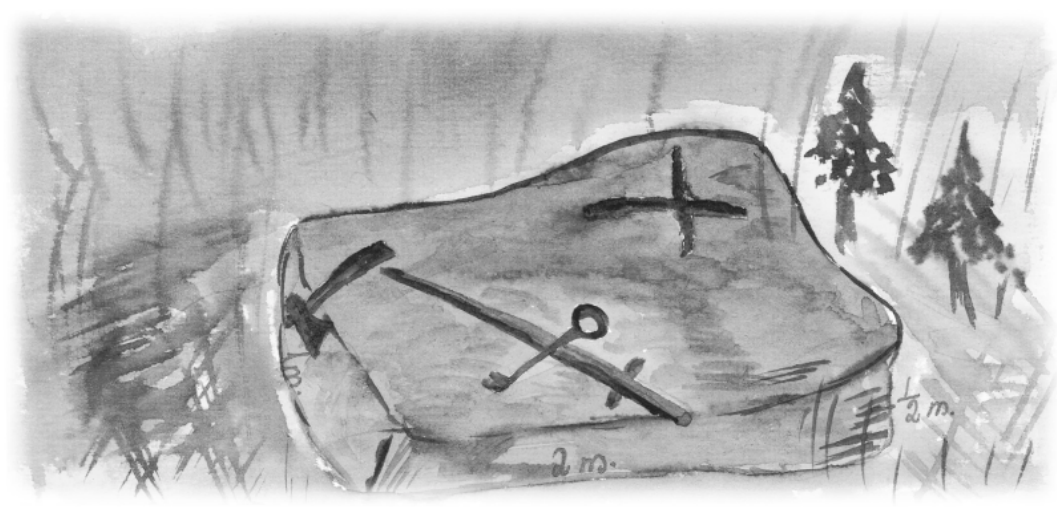

Joonis 2. Märkidega kivi kunagise Vastse-Antsla valla Sangaste metskonna ja Kassi vahtkonna piiril. Muistendi üleskirjutaja Laine Kallioni joonistus 1939 (ERA II 243, 269 (27)).

Sänna mõisa pargis endise härrastemaja ahervarte ligiduses võib veel näha suurt kivi, millesse on raiutud ussi pääd kujutav ornament, nool ja mõned tähed, mida aga enam aru ei saa.

Arvatakse, et sellest kivist noole suunas teatud maa kaugusel, nagu peab nendest tähtedest välja lugeda oskama, maetud kulda või muud varandust.

On ka kaevamisi ette võetud, kuid kes seda õiget kohta teab tabada Sellega kaevamised tagajärjetuks jäänud. Mõned jälle arvavad, et selle kivi lähedal teatud maa kaugusel olevat selle häärberi vaimud kägistanud mõisahärra, kelle käe läbi palju süütuid inimesi piinati surmani keldrites (ERA II 246, 373 (3) < Rõuge, Sänna v < Viitina v - E. Kaldmäe < Vidrik Kalnapenkis, 54 a (1939)).

Sänna mõisa pargis peituvaist varandustest leidub veel hiliseidki jutuüleskirjutusi (nt FAM 383 (9) < Rõuge - K. Koppel, H. Siimets < Jaan Valge, 52 a (1999)).

Muistendites kirjeldatakse enamasti juba valmis sümboleid kivil. Seegi pole reegel. Sain kontakti inimesega, kes kirjutas oma lapsepõlve tugevast elamusest, kuidas ta oli pealt näinud võõraste varanduseotsijate tegevust (memoraat esindab muistenditüüpi P 541 M. Jauhiaise tüpoloogia järgi, millest Eestist on üles märgitud vähemalt 200 varianti): 
Kui ma seakarjaga jõudsin kesale ja tahtsin minna eemal oleva suure kivi pääle istuma, nägin, et sääl oli kaks võõrast meest matkariietuses, kes omavahel agaralt rääkisid ja uurisid mingeid suuri pabereid või lehti. Jäin eemalt neid vahtima. Mehed läksid peatselt minema Kabelimäe suunas, mis oli osa meie naabritalu Vainu maast. Minust möödudes kuulsin neid rääkivat mingit võõrast keelt [---] Ö̈̈sel oli raiutud kivisse aastaarv 1924 ja kivist 30 sammu põhja poole oli kaevatud auk ning välja võetud mingi ümmarguse põhjaga nõu, mis oli jätnud tugeva selge jälje järele. Uudishimulisi käis hulgana nõu aset vaatamas ja samuti ka kivisse raiutud aastaarvu. Isa rääkis siis, et lugu mingist maa sisse peidetud varandusest, 30 sammu põhja poole suurest kivist, on olnud rahvasuus aastaid. Seda peetud naljaks (B. O. kirjast Mare Kaldale 16. jaanuarist 2001).

Meie kirjavahetus tekkis seetõttu, et proua B. O. oli sattunud lugema vaatlust võõrastest varanduseotsijatest, kus üheks näitejutuks oli sama varandusejutu üks variantidest (Kalda 1996).

Arhiivis leidub sellest sündmusest varasemaid salvestusi. Ühele neist on juurde kirjutatud kommentaar, et see on versioon Kodijärve vallas ringi liikunud jutust (ERA II 241,493/4 < Kambja, Kodijärve v - V. Ütt < üleskirjutaja ema (1939)).

Selgub, et mõnikord on võimalik välja selgitada, miks kivisse teatud laadi info raiuti. Järgmise juhtumi puhul ei ole kirjadega kivi kohta kasutada varandusejutuga versiooni, kuid märkide tegija isik ja tegemise eesmärgid on teada. 1920. aastatel otsiti Madisepäeva lahingu sündmuskohti ja tekitati Pärsti valla Tammemäele eestlaste vanema Lembitu matmispaiga kuulsus. Koduloo-uurija Jaan Vellema suhtus sellesse kui fakti ning on teada, et tema raiuski kümmekond aastat hiljem mäel asuvasse kivisse nime ja aastaarvu Lembitu 1227. Rahvapärimus vihjab küll sealsele hiiekohale, kuid juba 1920. aastate arheoloogilised kaevamised ei toonud mingeid tõendeid mingisugusest matusekohast Tammemäel (Västrik: 2001, http://www.zbi.ee/ uexkull/estonian/jyripaev.htm\#Vastrik; Veiksar 1982: 31-32). V. Västrik peab seda näiteks, kuidas inimene otsib maastikust märke kultuurilis-ajaloolise mälu kinnituseks. Antud juhul raius inimene oma otsinguid ja järeldusi kinnitavad märgid ka kivvi.

Arhiivi on jõudnud väärikas kogum võrdlemisi fragmentaarseid teateid kividest, kus huvitavat kivi ja märke üksnes kirjeldatakse, 
spetsiifiline jutumotiivistik (varandus, hiiu või vanapagana tegevus, kivistumine, nägemused-kummitused, pulmarongide kokkupõrge või sündmus - kellegi hukkamine vms) puudub või on samuti nimetamisi viidatud vaid mäletatud jutu teemale. Sellistele teadetele on mõnigi kord võimalik arhiivist kõrvale lehitseda siiski ka väljaarendatud jutu vormis märkmeid sama kivi kohta.

Ühest teatest saame vaid andmeid, et Alamusti kõrtsi läheduses oli hobuserauaga kivi (ERA II 243, 26 (11) < Kanepi, Valgjärve v I. Värv, Vana-Piigaste Algkool < Aleksander Värv, 45 a, üleskirjutaja isa (1939); siinkirjutaja neid märke kivilt enam ei leidnud). Tegelikult tunti samast paigast väljaarendatud süžeega jutte ja seda kõigis ümberkaudsetes külades nii Kanepi kui ka Põlva suunas. Paari süžee abil jutustati kivil viibinud Rootsi kuningast (hobuseraua jälje jättis kuninga hobune), peidetud varandusest või mõlemast teineteisega seoses.

Teateksjäämisel võib olla erinevaid põhjusi: konkreetse kivi kohta pole süžeelist juttu olnudki, informant vahendab lihtsalt oma tähelepanekuid ümbritseva suhtes; süžee on käibelt taandunud või informant ei soovi seda mingil põhjusel parajasti lisada. Kõik niisugused olukorrad on muistenditundmises, -levikus ja kogumistöös esindatud.

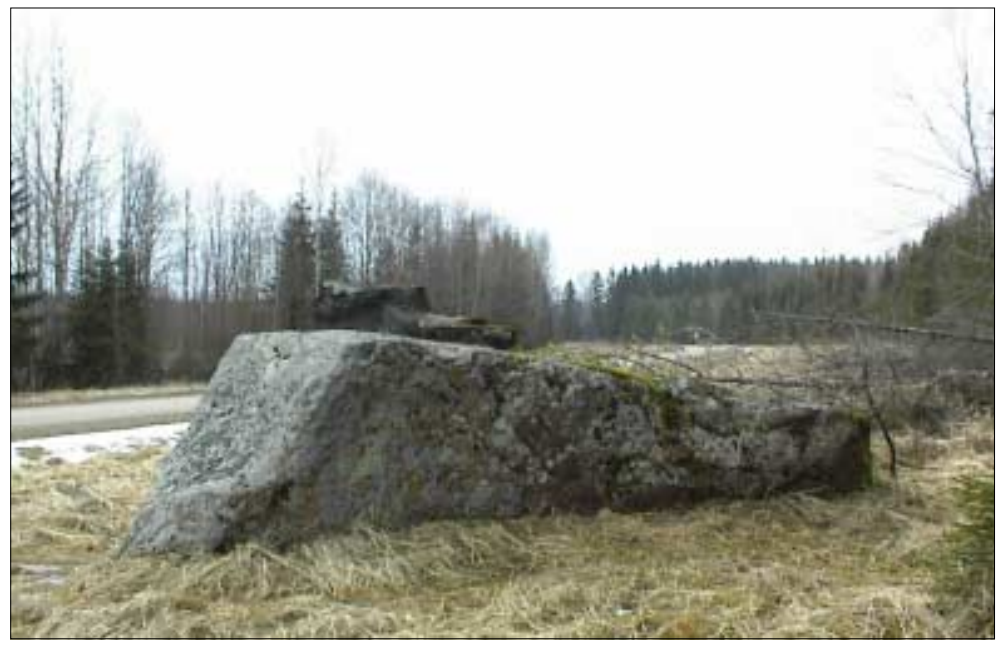

Joonis 3. Hobuserauaga kivi. Foto: Ain Kalda 2001. 


\section{Kas Rahakivid on olemas?}

Rahakivisid ei õnnestu seada ühte ritta kuulsamate nimega kividega. Näiteks Kuusalu Kuninga(te) kivist on arhiivis vähemalt 30 varianti Kuusalu, Haljala, Kadrina, ka Lüganuse ja Rakvere kihelkonna mõnedest küladest (kõigis ei rõhutata kivi nime) ning nimeliselt hästi tuntud on ju ka Lauritsakivi (kumbki ei osuta varandusele).

Rahakive leiame üliharva! Kui lähtuda tegelikkusest ja eeldada, et peideti üksnes enda tarbeks, siis ei ole põhjust loota iga kord laialt tuntud andmestikku. Samal ajal oli pärimuslik teave siiski rohkematele kättesaadav, oli sel siis reaalne taust või puudus see täiesti.

Umbes 400 kivi nimeteate hulgas on rahakive vaid kümmekond. Nimi ei pruugi isegi olla traditsiooniline, vaid üksnes muistendi üleskirjutaja või informandi rõhuasetus, tõlgendus, seega individuaalne arusaam. Traditsiooniline võib nimekasutus olla ehk väiksema rühma pärimuses, näiteks peresiseselt ja küla mingis piirkonnas (naabertaludes) või miks mitte näiteks laste traditsioonis. Missugune neist oletustest just iga kindla kivi puhul õige on, vajab järeleuurimist. Niisiis, kui kivi üldse nimeliselt teatakse, siis ei tulene see nimi peaaegu kunagi varanduse märgukivi olemisest. Ühtlasi ei pea arvama, et rahakivi all mõeldakse tingimata Rahakivi, s.t kivi määratletakse hoopis üldnimetuse kaudu, mida ei pea mõistma kui pärisnime. Siinkohal väärib siiski esiletoomist mõni neist erandjuhtumitest.

Raha kibi Alliku vallas Oisu külas sai ühe teate järgi nime inimeselt, kes unenäost saadud juhatuse järel sealt kastitäie hõberaha leidis, mees olevat seejärel ristinudki kivi Raha kibiks (ERA II 221, 385 (13) < Türi, Alliku v, Äiamäe k < Esna v, Korba k - V. Tõnissoo, Türi Progümnaasium < Ants Jaanimäe, 64 a, üleskirjutaja tuttav (1939)).

Seevastu Kullamäed on hoopis tavalisemad mõne üksiku ja kahtlase rahakiviga võrreldes (ka talunimena). Kullaga küla ümbruskonnast (Kambja vallas) on teada väga intensiivne aardepärimus, (aarde)tüpoloogiliselt mitmekesiseid tekste leidub Võnnu Kullamäelt (mäel oli olnud nimetu, kuid suunavate märkidega mõõga ja tähtedega - kivi, RKM I 5, 70 (3) < Võnnu - H. Mällo (1958); teise tõlgenduse järgi oli kivil kolm kitsejälge, RKM I 5, 184 (3) < Võnnu - V. Plekksepp (1958) - kivi ei ole alles). Kullamägi 
asub ka Otepää kihelkonnas Oandimäe naabruses (sellest on teada varandusejutt), Kambja ja Võnnu kihelkonna piiril Unikülas (varandusejutt on olemas, Rootsmäe \& Rootsmäe 1990 I: 15) ja Võnnu kihelkonnas Akali jõe suudmest umbes $3 \mathrm{~km}$ ülevalpool (Rootsmäe \& Rootsmäe 1990 I: 176, seal on ühtlasi kiviaja asulakoht). Võrumaal on Hõpõmägi, kus jutu perrä katlatäüs hõpõraha (H I 8, 374 (17) < Vastseliina < Rõuge - J. Sandra (1896)). Rahamäe mets oli näiteks Kooraste valla Kaagvere külas Seega talu tee ääres (ERA II 242, 665 (1) < Kanepi, Kooraste v, Kaagvere k - A. Hõbe, Kaagvere algkool < Emma Ingver, 34 a (1939) ja ERA II 242, 681(1) $<$ Kanepi, Kooraste v, Kaagvere k - E. Roosbaum, Kaagvere algkool $<$ vanaema (1939)).

Endise Raigla mõisa väljal Rasina vallas oli Varamägi, aarde suuruseks nimetatakse muistendis tündritäis kulda (ERA II 241, 112/3 (4) < Võnnu, Ahja v, Kopliaia k < Põlva, Himmaste k K. Aarik, Ahja algkool < Kusta Aarik, 50 a, üleskirjutaja isa (1939)).

Aardelugu mingist nimega kivist võidi teada, näiteks TagaSoomra küla Laikivist (RKM II 176, 13 (1) < Audru, Taga-Soomra k - E. Liiv < Tiiu Tuulmees (1964)), ka Helme Orjakivist (ERA II 236, 619/20 (10) < Helme, Koorküla v - Silvia Jõemets < Asta Jõemets, s 1927 (1939)). Nendest märkidega kivide osa on samuti hästi väike.

Niisiis kivi nimi (kui kivil on nimi) viitab varandusele väga harva, kuid muu nimega kivi võib olla aarde märgukivi või peidukoht. Aardejutt on üldse harva kohanime seletusjutu funktsioonis, mikrotoponüümikas tulevad siin kõne alla Kullamäed ja Hõpõmägi, suurema piirkonna kohanimede hulgas on vastavaid rahvaetümoloogilisi seletusi Kullamaa kohta. Kuid tunti ka hoopis vastupidise sisuga ütlust, et Kullamaal pole kulda, Märjamaal märga ega Vigalas viga (Jõgisalu \& Tihkan 1989: 149). Varanduseteadete rohkuse taustal on kohanimeseletuslike aardejuttude osatähtsus väike.

\section{(Märkidega) ohvrikivi kui varandusekivi}

Ka ohvrikividel nähti ja kirjeldati märke ja jooni. See iseenesest jällegi ei tähenda, et iga niisugune kivi oleks pidanud olema varandusetähis. Kuulsamatest kividest ei saanud varanduse märgukiviks näiteks Kuusalu Lauritsakivi, mis üksikute teadete järgi võis olla 
ohvrikivi (kivi joonis Tvauri 1997: 30 või http://haldjas.folklore.ee/ folklore/vol11/pics/tv13.htm). Märke sellel tõlgendati kui kääre, panni ja risti, varianditi kui põletusresti ja vererenne. Ohvrikivitähendust peetakse siiski kaheldavaks (Tvauri 1997: 33-34).

Kui ühe või teise informandi teada on ohvrikivi ühtlasi varanduse peidupaiga tähis, on enamikus variantides mõlemad aspektid esitatudki pigem informatiivselt, spetsiifilist jutusüžeed lisamata. Nii on ohvrikivina kirjeldatud Tumala lohkudega kivi (Tvauri 1997: 33 ja foto http://haldjas.folklore.ee/folklore/vol11/pics/tvf1.htm), mida kohalikus pärimuses teati tõepoolest varanduse peidukohana (Lõugas 1995: 81). Sama lugu on kiviga Russalu kandis metsas (RKM II 434, 305/6 (3) < Nissi, Riisipere v, Madila k - Mall Hiiemäe $<$ Rein Leheroo, s 1946 (1990)).

Lohke kividel seletati muistendeis kellegi jälgedeks, mõnedel juhtudel lisandus aardejutt. Lohukivid aga pole enamasti ohvrikivid (Tvauri 1997: 34). Selle teadmise varal kahaneb märkidega ohvrikivide ja varanduse märgukivide kokkulangevuse võimalus üpris väikseks ja juhuslikuks.

Teadete puhul ohvripaikadest on mõneti inspireeriv Rootsi etnoloogi Jonas Frykmani arutlus sellest, et suur osa kultuurist on varjatud, sõnatu teadmine. Seda õpetati ja õpiti pigem tegutsedes, mitte niivõrd kuulates (Frykman 1999: 73-74). Kas mitte selletõttu ei tundugi ohvripaikade kirjeldused rahvaluulekogudes mõnikord puised ja pingutatud? Et siin polnudki tähtsam mitte pärimuse vahendamine narratiivselt, vaid tegelikult: reaalajas minna pühasse kohta ja seal midagi füüsiliselt toimetada. See kõik ei eeldanud sugugi pikka juttu. Narratiivi kujundamiseks tekib vajadus etnoloogilise (või folkloristliku) intervjuu käigus, kuigi sõnastusi pärimusrühma liikmete jaoks ei või mõistagi kõrvale jätta. Teine lugu on tõesti stereotüüpsete muistendite puhul, mis haakusid ühe või teise loodusliku märgiga, kas või ohvrikiviga, kas või peidetud varanduse jutuna.

\section{Tegelikud aardeleiud}

Aeg-ajalt tuleb maapõuest välja peitleide, münte ja esemeid. Nende kirjeldusi leidub folkloorikogudeski, sest niisugune leid pole mitte igapäevane sündmus. Sellised juhtumid on andnud mõneks ajaks kõneainet ning tootnud üsna kindlapiirilisi memoraatseid lugusid. Üks suur erinevus hea klassikalise aardemuistendiga võrreldes 
on nende puhul jutuobjekti tõesuse säilitamine mitte ainult jutureaalsuses, vaid ka tegelikult. Kui mujal räägitakse pajatäitest rahast ja kullakoormatest, siis nendes vanadest õhukestest hõbemüntidest. Ka mütoloogilisi motiive ei lisata neil puhkudel peaaegu kunagi, ehk ainult isikliku kogemuse näitamiseks üldisemas kontekstis või siis kõige kergema mütoloogilise koormusega motiividena. Samal ajal innustavad niisugused leiud ja nende kirjeldamine omakorda teisi jutte meelde tuletama, meeles pidama ja ehk isegi uuesti looma (sellest ka Tolvanen 1968: 253 ja Hiiemäe: 2000c: 10). Tegelikult on niisuguste päriselt leitud rahade taustal kujunenudki jututüüp, kus kellegi talu edenemist seletatakse varanduseleidmise jutuga (soome traditsioonis tüüp P 521). Eriti varasematest aegadest on niisugused rahvapärased kirjeldused ka ainuke teade üldse sellest või teisest konkreetsest leiust, sageli kandsid leidjad või muidu juurde sattunud inimesed need lihtsalt laiali.

Peitleide on avastatud kivide lähedusest, aga märkide teema seisukohalt jääb niisugune kokkusattumus marginaalseks, kui märkidega rahakivide teema ise on kõrvaline. Küll aga toob selle lähem vaatlus tõestusi arvamusele, et peidukohta tähistav kivi on pigem tavaline ja suur vaid suhteliselt.

Ühendades siinse mõttekäigu vaatlusega ohvrikividest, lisagem siiski, et A. Tvauri toob oma artiklis mõningaid näiteid ohvrikivide lähedusest avastatud aaretest. Kõik tema 11 juhtumit on õieti arheoloogilised leiud, millest väikse osa moodustavad ohvriannid (Tvauri 1999: 39-40).

Üks kivi alla peidetud hõbeaare tuli välja Palamuselt 1997. aastal ja selle kohta ilmus sõnum ajalehes Postimees. Ajalehesõnumist loeme oletust, et varandus oli peidus just kivi all, kuigi on ju öeldud, et aare pudenes välja kanalisatsioonikraavi rajanud kopa vahelt. On huvitav ka tõsiasja rõhutamine: talu, mille maadelt hõbeaare leiti, olla keskajast kuni II maailmasõjani paistnud silma oma jõukusega. Ajaloolasest asjatundja oletas siiski, et raha võis matta pigem keegi võõras (Lõhmus 1997). Sama sõnumi võrguvariant on erinev: lühem, kuid pärimusseikade valik on kirjum, näiteks seostas kirjutaja aarde maa-aluste mõistega, mis on pakutud $e$-artikli pealkirjaks, ning teatas lugejale, et igal Eestimaa kivil ja künkal on oma nimi ja pärimus, http://arhiiv.postimees.ee/leht/97/06/02/ \#teine). Juuresoleval fotol (puudub e-Postimehes) näeme meest istumas umbes paraja pingi kõrgusel kivil, mis pildiallkirja järgi otsustades oligi see oletatav märgukivi. 


\section{Kokkuvõtteks}

Kui vaatleme kive pärimuses, selgub, et iga maastikulisest märgist kommunikatsiooni käigus kultuuriruumi märgiks saanud kivi kohta käibis piiritletud sisuga informatsioon. Arstikivi võis olla ohvrikivi, kuid mitte aarde tunnusmärk. Ohvrikivi võis osutada varandusekohale, kuid sedagi on pigem välditud või on tegu mingite kokkusattumustega. Muistendeis kivistunud olenditest tuleb ette kontaminatsioone varanduse peitmise lugudega, kuid seegi pole väga sagedane. Süžeesid ei olegi teab kui palju.

Üks või teine varandusejutt esitab tavaliselt stereotüüpse muistendisüžee. See jutustati aga rohkem või vähem täpselt määratletud koha jutuks. Traditsiooni kandjale oli koht ja koha lugu oma ja eriline. Varandusekoht ja jutt sellest moodustasid tervikinfo. Märgid kivil võisid pärimuse järgi juhatada varanduse peidukohale, mis ei tarvitsenud olla otse kivi külje all. Missugused märgid, missuguse kivi juures - selles usaldagem aga pärimuse asjatundlikkust. Kui oletada, et varandus ka tegelikult peideti, võiks arvata, et peitja tegi märgid-sümbolid kivile edaspidiseks ülesleidmiseks enda tarbeks. Kuigi nendest muutus kivi märgistatuks ja sellega rohkem või vähem väljapaistvaks teiste kivide seas, ei tähenda see kerget leidmisvõimalust. Märgid esitasid vaid koodi, mille võtit enam polnud. Rahaaugu lugude jutustamine ja nende järele pärimine sarnaneb siis võtmete proovimisele - võib-olla leidub ka sobiv.

\section{Kirjandus}

Eisen, Matthias Johann 1928. Rootsi kulda Eestis. Eesti Kirjandus XXII, lk 211-220.

Ernits, Enn 1997. Äänisjärve petroglüüfiq: miiq esäessi usk um kivvi raotu. Kaika Suvõülikuulõ kogomik I-VIII (1989-1996). Võro, lk 23-27.

Frykman, Jonas 1999. Asjad, mida me teeme, aga millest me harva räägime. Skandinaavia kultuurianalü̈̈s. Studia Ethnologica Tartuensia 3. Tartu, lk 73-91.

Hiiemäe, Mall 2000a.Tree as a sign on the landscape. Congressus nonus internationalis fenno-ugristarum 7.-13. 8. 2000 Tartu III. Summaria acroasium in sectionibus et symposiis factarum. Tartu, lk 27-28.

Hiiemäe, Mall 2000b. Puu kui märk maastikus. Käsikiri autori valduses.

Hiiemäe, Mall 2000c. Rannamõisa tamme lugu. Alatskivi.

Hiiemäe, Reet 2000. Kividest rahvapärimuses. Eesti Maaparandajate Seltsi Toimetised 4. Tallinn, lk 61-67. 
Jõekalda, Loit. Kes raius pildid kaljupinda? http://www.obs.ee/ emts/ ajakiri/kes_raius_pildid_kaljupinda.html

Jõgisalu, Harri \& Tihkan, Lembit 1989. Lugusid vanalt Läänemaalt. Tallinn.

Kalda, Mare 1996. Teadaanne härradele Majandusministeeriumi mäeasjandusosakonda. Mõnest varanduseotsimise loost. Vaga vares. Pro Folkloristica IV. Tartu, lk 53-60.

Kikkas, Ali 1997. Vanaaoliidsist kivvest. Kaika Suvõülikuulõ kogomik I-VIII (1989-1996). Võro, lk 70-71.

Laugaste, Eduard \& Normann, Erna 1959. Muistendid Kalevipojast. Monumenta Estoniae Antiquae II. Eesti muistendid. Hiiu- ja vägilasmuistendid I. Tallinn.

Laugaste, Eduard \& Liiv, Ellen 1970. Muistendid Vanapaganast. Monumenta Estoniae Antiquae II. Eesti muistendid. Hiiu- ja vägilasmuistendid III. Tallinn.

Lõhmus, Alo 1997. Palamuselt leiti ligi pool kilo hõbemünte. Postimees, 2. juuni, lk 2 ja http://arhiiv.postimees.ee/leht/97/06/02/\#teine

Lõugas, Vello 1995. Saaremaa väikeselohulised kultusekivid. Saaremaa muuseum. Kaheaastaraamat 1993-1994. Kuressaare, lk 62-88.

Poikalainen, Väino. Iidsed pildid Koola kaljudel. http://www.suri.ee/ esy/leht/99poik.html

Remmel, Mari-Ann 2001. Pulmateema loodusmaastikuga seotud muistendites. http://www.zbi.ee/ uexkull/estonian/jyripaev.htm\#Remmel

Rootsmäe, Lemming \& Rootsmäe, Ilse 1990. Võnnu kihelkonna kohanimed ja minevik. Tartu. Käsikiri Eesti Kirjandusmuuseumi Eesti Rahvaluule Arhiivis.

Tenjes, P. 1986. Petroglüüfidest ja kalendrist. Tartu Tähetorni kalender 1987. aastaks. Tallinn: Valgus, lk 81-91.

Tolvanen, Kari 1968. Toduudellisuuden kriteerit aarretarinoissa. Kalevalaseuran vuosikirja 48. Porvoo \& Helsinki, lk 244-268.

Tvauri, Andres 1997. Eesti lohukivid. Arheoloogilisi uurimusi 1. Tartu Ülikooli Arheoloogia Kabineti toimetised 9, Tartu, lk 11-53. Ingliskeelne $e$-versioon http://haldjas.folklore.ee/folklore/vol11/stones.htm

Tvauri, Andres 1999. Ohvrikividest. Mäetagused 11. Hüperajakiri. Tartu, lk 34-57 ja http://haldjas.folklore.ee/tagused/nr11/kivi.htm

Valk, Heiki 1999. Rural Cemeteries of Southern Estonia 1225-1800 $A D$. Visby \& Tartu.

Veiksar, Alfred 1982. Viljandi rajooni ajaloo- ja kultuurimälestised. Tallinn.

Västrik, Veinika 2001. Maastik ajaloolise mälu kandjana. Pärsti näide. http://www.zbi.ee/ uexkull/estonian/jyripaev.htm\#Vastrik 